\title{
FGFR4 Inhibitor H3B-6527
}

National Cancer Institute

\section{Source}

National Cancer Institute. FGFR4 Inhibitor H3B-6527. NCI Thesaurus. Code C128862.

An orally bioavailable inhibitor of human fibroblast growth factor receptor 4 (FGFR4), with potential antineoplastic activity. Upon administration, H3B-6527 specifically binds to and blocks FGFR4. This prevents the activation of FGFR4, inhibits FGFR4-mediated signaling and leads to an inhibition of cell proliferation in FGFR4-overexpressing tumor cells. FGFR4, a receptor tyrosine kinase overexpressed by certain tumor cell types, is involved in tumor cell proliferation, differentiation, angiogenesis, and survival; FGFR4 expression is associated with poor prognosis. 